\title{
Mercury (Hg) content in fish Meka (Xiphias sp.) in Fish Processing Unit and the local market in Manado and Bitung, North Sulawesi
}

\author{
Kandungan merkuri (Hg) pada ikan Meka (Xiphias sp.) di Unit Pengolahan Ikan dan \\ Pasar Lokal di Manado dan Bitung, Sulawesi Utara
}

\author{
Synthia I. Rondonuwu ${ }^{1}, \mathrm{~S}$. Berhimpon ${ }^{2}$, and Markus T. Lasut ${ }^{2 *}$ \\ IProgram Studi Magister Ilmu Perairan, Program Pascasarjana Universitas Sam Ratulangi. Jl. Kampus Unsrat Kleak, \\ Manado 95115, Sulawesi Utara, Indonesia. \\ ${ }^{2}$ Fakultas Perikanan dan Ilmu Kelautan, Universitas Sam Ratulangi. Jl. Kampus Unsrat Bahu, Manado 95115 , \\ Sulawesi Utara, Indonesia. \\ *E-mail: lasut.markus@unsrat.ac.id
}

\begin{abstract}
Meka fish (Xiphias sp.) is one of the many marine products besides tuna fishery. It has potential and a competitive price to become a main product for exports from Indonesia. However, data about its quality, including heavy metals contain, is still lack. This study aimed to analyze the concentration of mercury $(\mathrm{Hg})$ of the fish in three locations, i.e. the Fish Processing Unit, the local market in Manado, and Bitung. Fish consumption patterns of people living in Manado and Bitung and the risk of exposure to $\mathrm{Hg}$ to consumers based on the number of estimation of daily intake (EDI) and of Target Hazard Quotient (THQ) were also analyzed. The research found that there is a relationship between the concentration of $\mathrm{Hg}$ and the weight of the fish; the increase of weight is in line with the increase of $\mathrm{Hg}$ in which the greater weight of the fish is the higher levels of $\mathrm{Hg}$. Further analysis showed that, based on the EDI, the amount of $\mathrm{Hg}$ that consumed by the community of Manado and Bitung is greater than WHO standards, and based on the THQ analysis, it was found the risk of $\mathrm{Hg}$ exposure to the community in Bitung.
\end{abstract}

Keywords: meka fish; mercury; Hg, estimation of daily intake; target hazard quotient; North Sulawesi.

\begin{abstract}
Abstrak: Di Indonesia, ikan meka (Xiphias sp.) merupakan salah satu dari produk perikanan selain tuna, yang potensial dan memiliki harga yang kompetitif untuk menjadi andalan ekspor. Namun, data tentang mutu ikan ini, termasuk kandungan logam berat, masih kurang. Penelitian ini bertujuan untuk menganalisis kandungan merkuri (Hg) pada daging ikan ini di tiga lokasi, yaitu Unit Pengolahan Ikan (UPI), pasar lokal di Manado, dan pasar lokal di Bitung. Pola konsumsi ikan meka dari masyarakat yang tinggal di Manado dan Bitung, dan risiko bahaya terpapar Hg terhadap konsumen berdasarkan estimation of daily intake (EDI) dan Target Hazard Quotient (THQ) juga dianalisis. Dari hasil penelitian ditemukan, bahwa terdapat hubungan antara berat ikan dan kandungan $\mathrm{Hg}$; kenaikan berat ikan sejalan dengan kenaikan kandungan Hg. Dengan demikian, semakin besar berat ikan, maka akan semakin tinggi kandungan $\mathrm{Hg}$. Hasil analisis EDI menunjukkan, bahwa jumlah $\mathrm{Hg}$ yang masuk ke dalam tubuh pada masyarakat Manado dan Bitung lebih besar dari standar WHO. Berdasarkan hasil analisis THQ ditemukan, bahwa masyarakat Bitung berisiko terpapar $\mathrm{Hg}$.
\end{abstract}

Kata-kata kunci: Ikan meka; merkuri; Hg; estimation of daily intake; target hazard quotient; Sulawesi Utara.

\section{PENDAHULUAN}

Ikan merupakan sumber penting dari protein, mineral, vitamin, dan asam lemak tak jenuh, terutama omega-3. Hasil penelitian dari beberapa peneliti terdahulu mengindikasikan, bahwa mengkonsumsi ikan dapat mengurangi risiko penyakit jantung, tekanan darah tinggi, dan dapat mencegah beberapa penyakit arrhythmias cardiac. Walaupun demikian, mengkonsumsi ikan dapat juga menyebabkan gangguan terhadap kesehatan manusia, karena terpaparnya bahan-bahan kimia yang berbahaya (kontaminan), misalnya logam berat, seperti merkuri $(\mathrm{Hg})$, timbal $(\mathrm{Pb})$, dan kadmium $(\mathrm{Cd})$ (Kris-Etherton et al., 2002; Lasut and Yasuda, 2008; Lasut et al., 2010). Untuk mencegah hal ini terjadi, beberapa regulasi, sistem, dan metode telah dibuat dengan harapan dapat mencegah dan mengurangi kontaminan pada ikan. Sebagai contoh, yaitu melakukan analisis bahaya terhadap titik kritis dalam proses produksi (Hazard Analisis of Critical Control Point/HACCP); melakukan monitoring dan survei di 
unit pengolahan ikan (UPI), sebagai bagian dari konsep jaminan keamanan mutu hasil perikanan. Salah satu jenis ikan yang menjadi perhatian ialah ikan meka atau Swordfish (Xiphias sp.). Ikan jenis ini potensial dan memiliki harga yang kompetitif untuk menjadi andalan ekspor, khususnya di Provinsi Sulawesi Utara.

Berdasarkan hasil monitoring yang dilakukan oleh Food and Drug Administration (FDA) pada tahun 1990-2010 (FDA, 2010), ikan meka berada pada urutan ketiga dari ikan yang mengandung $\mathrm{Hg}$ tertinggi, setelah mackerel king dan hiu. Kecenderungan permintaan pangsa ekspor ikan meka cukup besar di Asia, Eropa, dan USA. Selain harganya sangat kompetitif, ikan ini sangat digemari karena tekstur daging dan rasanya yang khas. Sejauh ini, data mutu (termasuk konsentrasi logam berat) tentang ikan ini masih sangat sedikit diperoleh karena, antara lain, jumlah stok ikan yang masih terbatas dari hasil tangkapan nelayan, periode musim tangkap belum valid, dan area fishing ground yang jauh. Karena harga yang kompetitif menyebabkan ikan meka memiliki permintaan ekspor yang tinggi dari negara tujuan ekspor terutama dari Uni Eropa, Asia Timur, dan USA. Namun demikian, pemberlakuan standar mutu yang ketat terhadap produk ini, terutama kadar konsentrat logam berat, seperti $\mathrm{Hg}$ dari negara-negara importir di Asia, Uni Eropa, dan USA menjadikan produk ini rentan terhadap penolakan.

Mengingat masih sedikitnya data tentang ikan ini, terutama komposisi konsentrat kontaminan logam berat, seperti merkuri, yang merupakan parameter krusial sebelum produk ini didistribusikan dan dipasarkan di dalam negeri maupun luar negeri, serta sebagai upaya untuk mendukung efektivitas pengendalian dan peningkatan atas tuntutan jaminan keamanan mutu hasil perikanan, maka perlu dilakukan monitoring mutu terhadap produk perikanan sebelum dan akan diekspor melalui uji laboratoris. Untuk itu, dipandang penting untuk dilakukan penelitian konsentrasi logam berat $\mathrm{Hg}$ pada daging ikan meka (Xiphias sp.), sebagai bagian jaminan keamanan mutu sebelum produk ini dipasarkan ke luar maupun di dalam negeri.

Penelitian ini bertujuan untuk menganalisis konsentrasi $\mathrm{Hg}$ pada daging ikan meka atau Swordfish (Xiphias sp.) di Unit Pengolahan Ikan (UPI) eksportir, pasar lokal di Manado, dan Bitung, serta mengevaluasi keberadaannya. Selanjutnya menganalisis pola konsumsi ikan meka dari masyarakat yang tinggal di Manado dan Bitung, serta menilai resiko bahaya terpapar $\mathrm{Hg}$ terhadap konsumen berdasarkan jumlah asupan perminggu yang diperbolehkan (provisional tolerable weekly intake) menurut standar FAO dan WHO.

\section{MATERIAL DAN METODE}

Penelitian ini dilaksanakan selama 2 bulan, yaitu Juli dan Agustus 2013, dengan tiga lokasi pengambilan sampel, yaitu di Pasar Bersehati di Manado (Lokasi 1), Pasar Winenet di Bitung (Lokasi 2), dan Unit Pengolahan Ikan Eksportir di Bitung. Sampel diambil sebanyak 10 sampel pada masing-masing lokasi, dengan teknik pengambilan sampel menggunakan teknik "sembarang" (haphazard) terhadap ikan meka yang diketahui beratnya. Pengukuran berat ikan dilakukan di lokasi pengambilan sampel.

Sebanyak 10 sampel potongan ikan meka seberat $500 \mathrm{~g}$, yaitu potongan daging di bagian punggung, perut, dan ekor dari tiap ikan, diambil di tiga lokasi berbeda, kemudian diberi tanda/label dengan menuliskan lokasi pengambilan sampel dan berat ikan meka. Selanjutnya, sampel dibawa untuk diuji kandungan merkuri di Laboratorium Balai Pengujian dan Sertifikasi Hasil Perikanan (BPSHP) Provinsi Sulawesi Utara di Bitung.

Data konsumsi ikan diambil dengan menggunakan angket (kuesioner), pada seratus orang responden yang mengkonsumsi ikan meka di dua lokasi, yaitu Lokasi 1 (masyarakat di Kecamatan Malalayang, Kota Manado; yang ditemui di rumah pribadi dan rumah makan; serta konsumen ikan meka di pasar Bersehati Manado, sebanyak 50 orang) dan Lokasi 2 (masyarakat atau konsumen yang ditemui di Pasar Winenet Bitung; sebanyak 50 orang).

Data dianalisis sesuai dengan tujuan yang ditetapkan, yaitu pertama: analisis hubungan antara konsentrasi merkuri total dengan berat ikan, dianalisis menggunakan persamaan linier regresi: $Y$ $=\mathrm{a}+\mathrm{bX}$; di mana $\mathrm{Y}$ : variabel konsentrasi $\mathrm{Hg} ; \mathrm{X}$ : variabel berat ikan. Kemudian, Analisis Risiko Potensi Bahaya Terhadap Kesehatan Konsumen dilakukan menggunakan metode persamaan Estimation of Daily Intake (EDI), yang dikembangkan oleh Kotsanis et al. (2001) dalam Africa et al. (2009) sebagai berikut:

$$
\mathrm{EDI}=\frac{\mathrm{C} \times \text { Cons }}{\mathrm{Bw}}
$$

di mana C: konsentrasi Hg pada ikan; Cons: jumlah konsumsi ikan/orang/hari; Bw: berat badan per orang.

Estimasi Target Hazard Quotient (THQ) dianalisis menurut panduan US EPA (2000) dengan rumus sebagai berikut: 
Rondonuwu et al.: Mercury (Hg) content in fish Meka (Xiphias sp.) in Fish Processing Unit...

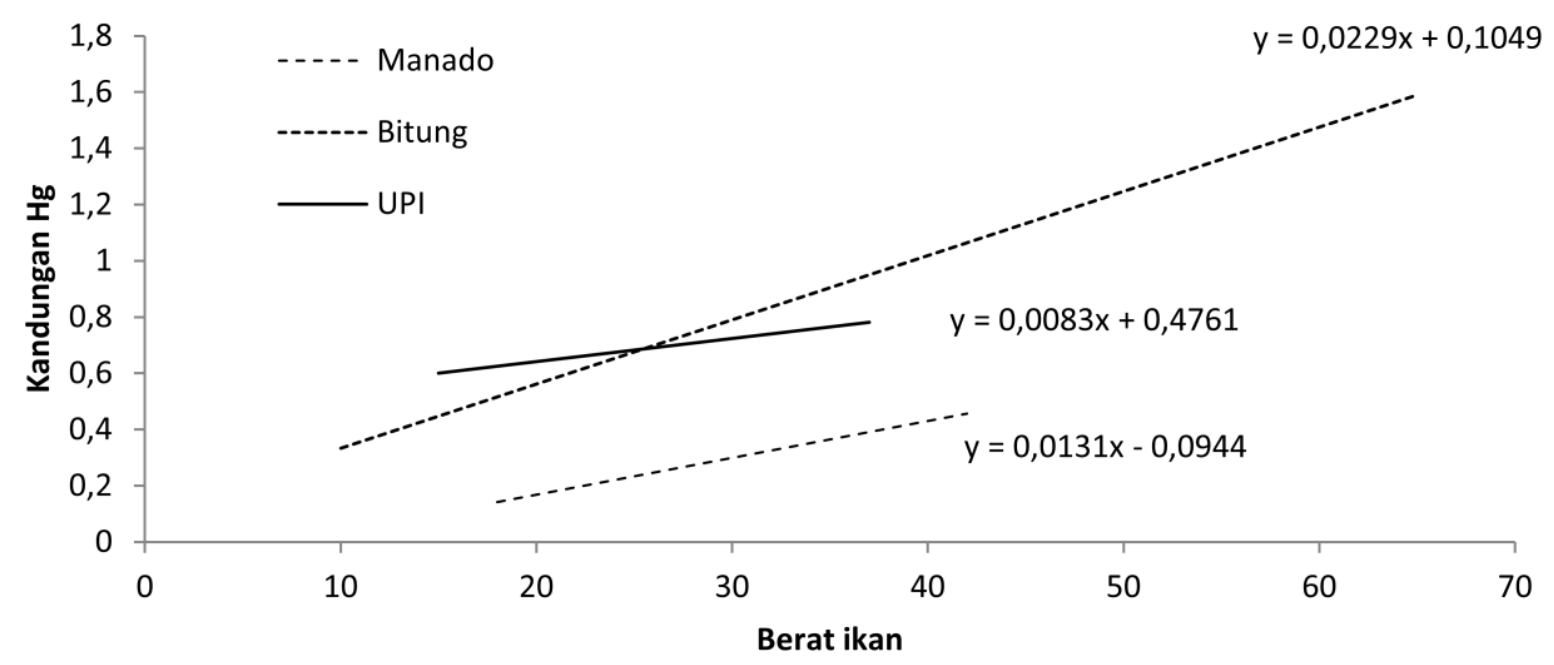

Gambar 1. Hubungan kandungan merkuri ( $\mathrm{Hg})$ dan berat ikan meka (Xiphias sp.) di tiga lokasi.

$$
\mathrm{THQ}=\frac{\text { Efr } \times \text { EDtot } \times \text { SFI } \times \text { MCS }}{\text { RfDo } \times \text { Bwa } \times \text { Atn }} \times 10^{-3}
$$

di mana EFr: frekuensi terpapar (365 hari/tahun); EDtot: lamanya terpapar (tahun); SFI: jumlah asupan makanan laut (gram/hari); MCS: konsentrasi logam berat dalam daging ikan $(\mu \mathrm{g} / \mathrm{g}=\mathrm{ppm})$; RFDo: dosis referensi asupan $(\mathrm{mg} / \mathrm{kg} / \mathrm{hari})$; BWa: berat badan; ATn: rata-rata waktu terpapar tanpa menimbulkan bahaya kanker (Edtot x 365 hari/tahun).

Estimasi THQ adalah indeks risiko yang terkait dengan paparan jangka panjang terhadap bahan kimia berdasarkan referensi batas atas yang aman. Kriteria hasil penilaian THQ adalah sebagai berikut: (a) Jika THQ $\leq 1$ berarti tidak ada resiko, dan (b) Jika THQ $>1$ berarti ada resiko.

\section{HASIL DAN PEMBAHASAN}

Hasil pengujian kandungan $\mathrm{Hg}$ menunjukkan, bahwa pada sampel ikan yang diambil di pasar Bersehati Manado memiliki kandungan $\mathrm{Hg}$ terendah sebanyak 0,040 ppm, yang diukur pada ikan dengan berat 18 $\mathrm{kg}$, sedangkan kandungan $\mathrm{Hg}$ tertinggi sebanyak 0,442 ppm, diukur pada ikan dengan berat $42 \mathrm{~kg}$. Dibandingkan dengan sampel ikan yang diambil di pasar Winenet Bitung, kandungan $\mathrm{Hg}$ terendah sebanyak 0,225 ppm, diukur pada ikan dengan berat $10 \mathrm{~kg}$ dan tertinggi sebanyak $1,417 \mathrm{ppm}$, diukur pada ikan dengan berat $65 \mathrm{~kg}$; sedangkan, di Unit Pengolahan Ikan kandungan $\mathrm{Hg}$ terendah sebanyak $0,569 \mathrm{ppm}$, diukur pada ikan dengan berat $15 \mathrm{~kg}$ dan tertinggi sebanyak $0,814 \mathrm{ppm}$, diukur pada ikan dengan berat $37 \mathrm{~kg}$. Hasil pengujian kandungan $\mathrm{Hg}$ pada sampel ikan di Bitung cenderung lebih tinggi dibandingkan dengan 2 lokasi lain, yaitu Manado dan UPI. Hal ini disebabkan karena sampel ikan di Bitung memiliki kisaran ukuran (berat) lebih besar, yaitu ikan berukuran kecil (10 kg) sampai ikan berukuran besar $(65 \mathrm{~kg})$, sedangkan di Manado dan UPI sampel terdiri dari ikan berukuran antara 15-42 $\mathrm{kg}$.

Gambar 1 menampilkan hubungan kandungan $\mathrm{Hg}$ dan berat ikan meka di 3 lokasi penelitian. Dari Gambar 1 dapat dilihat bahwa kenaikan kandungan $\mathrm{Hg}$ sejalan dengan kenaikan berat ikan; di mana semakin besar berat ikan maka akan semakin tinggi kandungan $\mathrm{Hg}$, demikian pula sebaliknya. Fenomena ini dapat terjadi berdasarkan habitat, ukuran, sifat, serta jenis makanan ikan tersebut. Merkuri $(\mathrm{Hg})$ dapat masuk melalui rantai makanan dan jenis ikan predator yang mempunyai ukuran besar di mana proses memangsa diikuti oleh proses akumulasi (Monteiro dan Lopes, 1990; Storelli dan Macrotrigiano, 2001). Hal ini sejalan juga dengan pernyataan Klemmer et al. (1976) yang melakukan penelitian pada beberapa ikan yang berbeda tingkatan tropik menyatakan, bahwa kandungan konsentrasi merkuri pada ikan-ikan tersebut berbeda sangat signifikan untuk masing-masing ikan pada tingkatan tropik. Selanjutnya Denton dan BurdonJones (1986) menambahkan, bahwa konsentrasi merkuri berkorelasi positif terhadap ukuran dan tingkatan tropik ikan dalam rantai makanan. Selanjutnya Burger et al. (2004) menyatakan, bahwa akumulasi maksimum logam berat $\mathrm{Hg}$ melalui proses bioakumulasi terdapat pada kelompok ikan predator yang berada di puncak tingkatan tropik. Dikatakan pula, bahwa bioakumulasi beberapa unsur logam 
Tabel 1. Perhitungan Estimation of Daily Intake (EDI)

\begin{tabular}{lcccc}
\hline Lokasi & $\begin{array}{c}\mathrm{Hg} \\
(\text { Rerata })\end{array}$ & $\begin{array}{c}\text { EDI } \\
(\mathrm{L})\end{array}$ & $\begin{array}{c}\text { EDI } \\
(\mathrm{P})\end{array}$ & $\begin{array}{c}\text { EDI } \\
\text { Total }\end{array}$ \\
\hline Manado & 0,310 & 0,236 & 0,482 & 0,216 \\
Bitung & 0,679 & 0,447 & 0,331 & 0,390 \\
\hline
\end{tabular}

L: Laki-laki

P: Perempuan

berat pada ikan berkaitan erat dengan ukuran dan umur ikan.

Selanjutnya dengan perhitungan sesuai rumus diperoleh, bahwa nilai EDI terendah di Lokasi 1 (Manado) adalah $0,010 \mathrm{mg} / \mathrm{kg}$, yaitu pada responden perempuan berumur 33 tahun dengan berat badan 55 $\mathrm{kg}$ di mana responden tersebut mengkonsumsi $100 \mathrm{~g}$ ikan meka dalam seminggu. Sedangkan nilai EDI tertinggi adalah $0,997 \mathrm{mg} / \mathrm{kg}$, yaitu pada responden laki-laki berumur 63 tahun dengan berat badan $57 \mathrm{~kg}$ di mana responden tersebut mengkonsumsi $300 \mathrm{~g}$ ikan meka sebanyak 3 kali dalam seminggu.

Pada hasil survei di Lokasi 2 (Bitung), ditemukan nilai EDI terendah adalah sebesar 0,049 $\mathrm{mg} / \mathrm{kg}$ pada responden perempuan berumur 30 tahun dengan berat badan $65 \mathrm{~kg}$ di mana responden tersebut mengkonsumsi ikan meka sebanyak $100 \mathrm{~g}$ dalam seminggu. Nilai EDI tertinggi adalah $1,687 \mathrm{mg} / \mathrm{kg}$ pada responden laki-laki berumur 29 tahun, berat badan $48 \mathrm{~kg}$, mengkonsumsi ikan meka sebanyak 200 g 2 kali seminggu.

Tabel 1 menampilkan hasil perhitungan ratarata EDI di Lokasi 1 (Manado) dan Lokasi 2 (Bitung). Mengacu pada standar WHO tentang jumlah merkuri yang boleh masuk ke tubuh manusia berdasarkan PTWI (Provisional Tolerable Weekly Intake) adalah 0,3 ppm total merkuri atau 0,2 ppm metal merkuri per minggu per $70 \mathrm{~kg}$ berat badan atau 0,04 ppm/hari, maka pola konsumsi ikan Meka pada masyarakat Manado rata-rata $211 \mathrm{~g} /$ minggu melebihi ambang batas standar WHO jika mengkonsumsi ikan meka lebih dari $18 \mathrm{~kg}$ atau ikan dengan kandungan merkuri lebih dari 0,040 ppm (kandungan terendah). Hal yang sama berlaku juga pada masyarakat Bitung dengan pola konsumsi rata-rata $160 \mathrm{~g} /$ minggu, dengan berat ikan meka lebih dari $10 \mathrm{~kg}$ atau dengan kandungan merkuri lebih dari 0,225 ppm.

Estimasi THQ dengan mengasumsikan pola asupan per minggu sebanyak $100 \mathrm{~g}$ atau sekitar 14 $\mathrm{g} / \mathrm{hari}$, dan pengelompokan nilai minimum, median, dan maksimun dari umur dan berat badan responden di dua lokasi (Manado dan Bitung), ditampilkan dalam Tabel 2. Pada tabel tersebut dapat dilihat, bahwa indeks THQ di Lokasi 1 (Manado) semuanya menunjukkan nilai $<1$, sedangkan indeks THQ di Lokasi 2 (Bitung) terdapat nilai $>1$, yaitu THQ = 1,30 pada kelompok umur 15 tahun dengan kandungan $\mathrm{Hg}$ kelompok median $(0,659 \mathrm{ppm})$ dan THQ $=2,82$ pada kelompok umur 15 tahun dengan kandungan $\mathrm{Hg}$ kelompok maximum (1,417 ppm), juga pada kelompok umur 36 tahun, yaitu THQ = 1,31 pada kelompok umur 36 tahun dengan kandungan $\mathrm{Hg}$ kelompok maksimum (1,417 ppm). Indeks THQ > 1 menunjukkan, bahwa terdapat risiko kesehatan pada konsumen. Ada dua organ tubuh manusia yang menjadi target dari akumulasi terpapar merkuri sehingga menyebabkan gangguan kesehatan pada manusia, yaitu ginjal dan sistem pusat saraf (Goyer et al., 2004). Namun, estimasi THQ tidak mendifinisikan hubungan antara dosis dengan respons/akibat dan nilai tersebut tidak boleh dianggap sebagai perkiraan langsung terhadap risiko (US EPA 1996).

\section{KESIMPULAN}

Berdasarkan hasil penelitian, tiga hal dapat disimpulkan, yaitu:

- Kandungan Hg pada ikan meka atau Swordfish (Xiphias sp.) di Unit Pengolahan Ikan eksportir, pasar lokal Manado, dan Bitung, bervariasi

Tabel 2. Estimasi Target Hazard Quotient (THQ) dengan pola asupan 14 g/hari di Lokasi 1 (Manado) dan Lokasi 2 (Bitung)

\begin{tabular}{|c|c|c|c|c|c|}
\hline \multirow{5}{*}{$\begin{array}{l}\text { Lokasi } 1 \\
\text { (Manado) }\end{array}$} & \multirow{2}{*}{\multicolumn{2}{|c|}{$\begin{array}{c}\text { Kandungan } \mathrm{Hg} \\
(\mathrm{ppm})\end{array}$}} & \multicolumn{3}{|c|}{ THQ } \\
\hline & & & $8 \mathrm{thn} / \mathrm{BB} 24 \mathrm{~kg}$ & $37 \mathrm{thn} / \mathrm{BB} 54 \mathrm{~kg}$ & $78 \mathrm{thn} / \mathrm{BB} 75 \mathrm{~kg}$ \\
\hline & Minimum & 0,040 & 0,05 & 0,04 & 0,03 \\
\hline & Nilai Tengah & 0,340 & 0,40 & 0,31 & 0,23 \\
\hline & Maksimum & 0,442 & 0,52 & 0,41 & 0,29 \\
\hline \multirow{5}{*}{$\begin{array}{c}\text { Lokasi } 2 \\
\text { (Bitung) }\end{array}$} & \multicolumn{2}{|c|}{ Kandungan $\mathrm{Hg}$} & & THQ & \\
\hline & \multicolumn{2}{|c|}{$(\mathrm{ppm})$} & $15 \mathrm{thn} / \mathrm{BB} 25 \mathrm{~kg}$ & 36 thn/BB $54 \mathrm{~kg}$ & $63 \mathrm{thn} / \mathrm{BB} 75 \mathrm{~kg}$ \\
\hline & Minimum & 0,225 & 0,45 & 0,21 & 0,14 \\
\hline & Nilai Tengah & 0,659 & 1,30 & 0,61 & 0,44 \\
\hline & Maksimum & 1,417 & 2,82 & 1,31 & 0,94 \\
\hline
\end{tabular}


berdasarkan ukuran berat di mana semakin besar ukuran ikan maka semakin tinggi kandungan merkuri. Pada ukuran berat ikan > $20 \mathrm{~kg}$ memiliki kandungan merkuri melebihi $0,5 \mathrm{ppm}$ sehingga tidak aman untuk dikonsumsi dan tidak bisa diekspor ke negara lain.

- Pola konsumsi ikan meka pada masyarakat Manado dan Bitung termasuk tinggi dan cenderung tidak aman; jumlah merkuri yang boleh masuk ke dalam tubuh manusia pada masyarakat Manado dan Bitung lebih besar dari dosis referensi WHO yaitu $0,04 \mathrm{ppm} / \mathrm{hari}$.

- Ditemukan risiko paparan merkuri pada masyarakat di Bitung, di mana konsumsi 100 g/minggu ikan meka dengan berat $>20 \mathrm{~kg}$ menyebabkan nilai THQ > 1,0.

\section{REFERENSI}

AFRICA, C.R., Pascual, A.F. and Santiago, E.C. (2009) Total mercury in three fish species sold in a metro manila public market: monitoring and health risk assesment. Science Diliman, 21(1), pp. $1-6$.

BURGER, J. and Gochfeld, M. (2005) Fish availability in supermarket and fish markets in New Jersey. Science of the Total Environment, 166-161, pp. 653-659.

DENTON, G.R.W. and Bourdon-Jones, W. (1986) Trace metal in fish from the Great Barrier Reef. Marine Pollution Bulletin, 20, pp. 353- 357.

FDA, 2010. Mercury levels in commercial fish and shellfish (1990-2010). Food and Drugs Administration(FDA) Monitoring Program.

GOYER, M., GOLUP, CHOUGHURY, H., HUGHES, M., KENYON, E. and STIFEMEN, M. 2004. Issue papper on the human health effects of metals, pp. 1-13.
KLEMMER, H.W., UNNINAYER, C.S. and OKUBO, W.I. (1976) Mercury content of biota in coastal waters in Hawaii. Bulletin Environmental Contamination Toxicology, 15, pp. 454-457.

KRIS-ETHERTON, P.M., HARRIS, W.S. and APPEL, L.J. (2002) Fish Consumption, fish oil, omega-3 fatty acids, and cardiovascular disease. American Heart Association, Nutrition Committee.

Lasut, M.T. and Yasuda, Y. (2008). Accumulation of mercury in marine biota of Buyat Bay, north Sulawesi, Indonesia. Coastal Marine Science 32(1): 33-38.

Lasut, M.T., Yasuda, Y., Edinger, E.N., and Pangemanan, J.M. (2010). Distribution and accumulation of mercury derived from gold mining in marine environment and its impact on residents of Buyat Bay, north Sulawesi, Indonesia. Water, Air \& Soil Pollution, 208: 153164. DOI 10.1007/s11270-009-0155-0.

MONTEIRO, L.R., COSTA, V., FURNESS, R.W. and SANTOS, R.S. (1996) Mercury concentration in prey fish indicate enhanced bioaccumulation in mesopelagic environments. Marine Ecology Progress Series, 141, pp. 21-25.

STORELLI, M.M. and Macrotrigiano, G.O. (2001) Total mercury levels in muscle tissues of swordfish (Xiphias gladius) and bluefin tuna (Thunnus thynnus) from the Mediterranean Sea (Italy). Journal of Food Protection, 64, pp. 10581061.

US EPA, 2000. Risk Based Concentration Table, Region III.

Diterima: 10 Juli 2015

Disetujui: 31 Juli 2015 